\title{
Text Messages Based Interventions for Pregnant Women's Health: Systematic Review
}

\author{
Ayse Sezer Balci ${ }^{1}$ (D) Hasibe Kadioglu² (iD) \\ ${ }^{1}$ Marmara University, Health Science Faculty, Department of Public Health Nursing, Istanbul, Turkey \\ ${ }_{2}^{2}$ Marmara University, Health Science Faculty, Department of Public Health Nursing, , Istanbul, Turkey \\ Correspondence Author: Ayse Sezer Balci \\ E-mail: ayses_18_9@hotmail.com
}

Received: 07.01.2018 Accepted: 07.03.2018

\begin{abstract}
Objective: The aim of this systematic review was to summarize evidence for the effectiveness of text message-based randomized controlled studies for the health of pregnant women.

Methods: We searched the following databases from 2005 and 2015, using databases Google Scholar, Pubmed, Ovid, Cochrane Library. The question of this systematic review; what are results of text message-based interventions on the health of pregnant women? Total of 15 articles was received that met the inclusion criteria for the study. After each full article was read, fifteen articles were included in this review.

Results: Text message were effective on smoking cessation, weight control, diabetes management, motherhood readiness, developing negative attitudes towards alcohol consumption.

Conclusion: This systematic review suggests use of text message is more practical and cost-effective method for promoting the health of pregnant women and they had a positive effect on health practices of pregnant women.

Keywords: health applications, mobile health, pregnant women, primary care, text message.
\end{abstract}

\section{INTRODUCTION}

Use of mobile health applications (mHealth) in developing healthcare and healthy lifestyle behaviors has increased in recent years $(1,2)$. World Health Organization (WHO) defines mHealth applications as supporting the public health and medical practices through mobile phones, patient follow-up monitors, personal digital assistant, other wireless devices (3). Some of the mobile health applications are formed as a reminder system in the smoking cessation, weight control and disease management and treatment for diabetes (4, 5). Mobile phones have a privileged place among the other mobile applications due to their properties such as being ubiquity, mobility, continuity and multi-media methods $(2,6)$. Sending a text message (SMS) is the simpler format commonly used among mobile health applications $(7,8)$. Healthrelated functions of the text messages include reminding health behaviors, reminding scheduled appointments and medication intake, notification of clinical test results, notification of health status, promotion of positive health behaviors, and increasing self-efficacy by giving information about access to information and sources $(9,10)$. Promotion of maternal-infant health is one of the fields where the mobile health applications has increased. Pregnant women and mothers can be encouraged by this way for many health behaviors during prenatal and postpartum periods (11,
12). SMS intervention studies on the importance of mobile technology in health promotion and pregnancy complication readiness, pregnant woman viewed the SMS intervention as useful in maternal healthcare services (13). The aim of this systematic review was to summarize evidence for the effectiveness of text message-based randomized controlled studies for the health of pregnant women.

\section{METHODS}

The question of this systematic review was "What are results of short message-based interventions on the health of pregnant women?

\subsection{Search Strategy}

The systematic review included articles published between 2005 and 2015 and was performed in accordance with the Centre for Reviews and Dissemination 2009 (CRD)'s guideline (14). The question of this systematic review, "What are results of text message-based interventions on the health of pregnant women? We used for data summarizing "Checklist of Preferred Reporting Items for Systematic Reviews and Meta-Analyses Statement (PRISMA) which is a valid and reliable guideline $(15,16)$. We performed searches on: 
Google Scholar, Pubmed, Ovid, Cochrane Library databases with the keywords of "pregnancy" and "text message".

Inclusion criteria for the review included studies focused on the use of text messages with randomized controlled trial interventions for pregnant health.

\subsection{Critical Appraisal}

Quality evaluation of randomized controlled trials was conducted independently by the two authors. The methodological quality of eligible randomized controlled trials was assessed using tool developed by the Cochrane Collaboration (17).

According to our systematic literature review, 15 randomized controlled studies were included in the review. Ten of the articles examined within the scope of this review had low risk in Random Sequence Generation. Eight studies had low risk in Allocation concealment; whereas, 7 had uncertain risk (Figure 1).

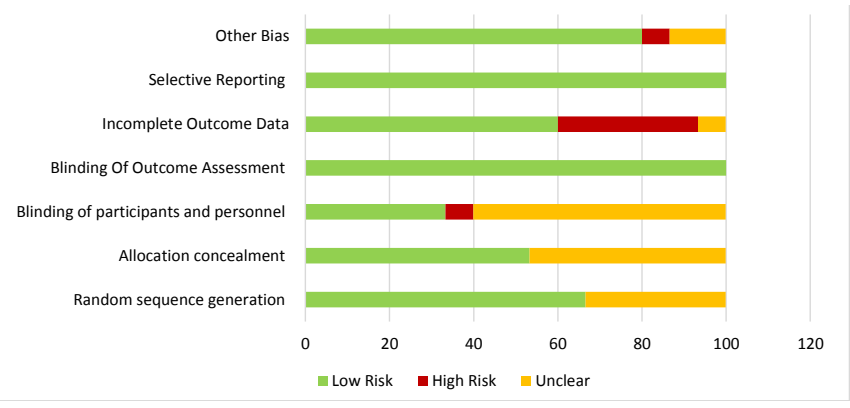

Figure 1. Risk of bias

\section{RESULTS}

After reading each one full article 15 randomized controlled studies were involved in this systematic review study (Figure 2). There were three studies Text 4 baby program, three studies having influenza vaccine, two studies smoking reduction and cessation, two studies prevention of gestational diabetes, two studies increasing of health knowledge and awareness in pregnancy, one studies reducing anxiety in screening tests, one studies prevention of obesity, one studies having HIV test.

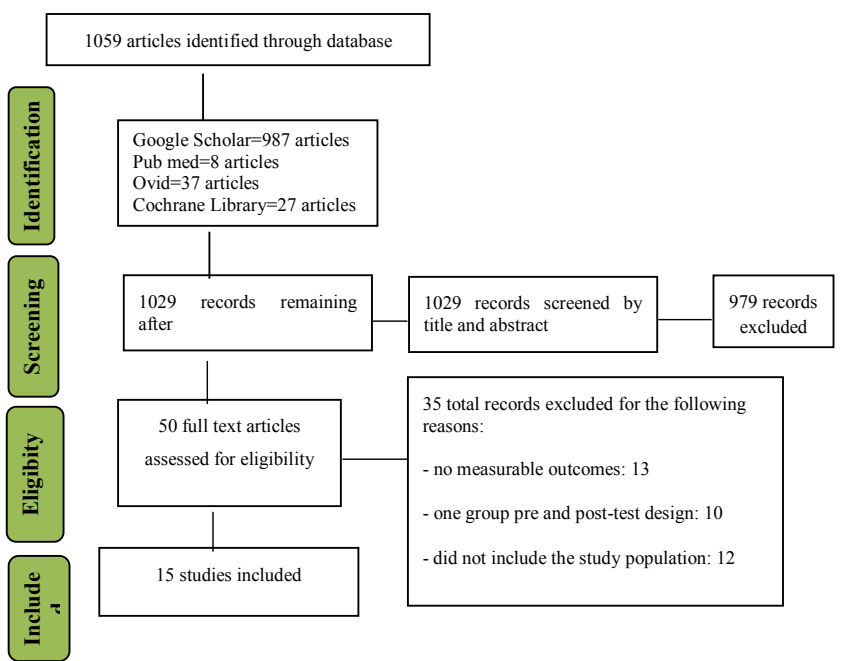

Figure 2. PRISMA Flow diagram for literature search

\subsection{Effect of Text Messages on Smoking Cessation- Reduction}

Result of studies pregnant woman's self-efficacy, beliefs about its harms and quitting commitment scores increased, frequency of 7 day staying away from smoking of the was found to be increased. The amount of smoking was decreased. Also warning messages about reducing smoking gradually were found more effective $(18,19)$ (Table 1$)$.

\subsection{Effect of Text Messages on Influenza vaccine}

Vaccination in pregnancy helps to protect newborns both through passive transfer of immunity (20). Result of one studies was determined that text message did not affect the influenza vaccination (21). Jordan et al. (2015) was found that vaccination rate was increased with text mesagges. Also reminder messages increased the vaccination possibility among pregnant women and mothers who thought to be vaccinated (22). 
Table 1. Summary of literature rewiev

\begin{tabular}{|c|c|c|c|}
\hline Research & Sampling & Program Applied & Results \\
\hline $\begin{array}{l}\text { Naughton et } \\
\text { al. (2012) }\end{array}$ & $\begin{array}{l}\text { Experimental } \\
\text { Group }=102 \\
\text { Control Group }=105\end{array}$ & $\begin{array}{l}\text { Text messages were sent two times daily to help the } \\
\text { experimental group to quit smoking by themselves for } \\
11 \text { weeks, } \\
\text { A general brochure was sent to the control group. }\end{array}$ & $\begin{array}{l}\text { The probability of setting a date to quit smoking } \\
(p=0.04) \text {, self-efficacy }(p=0.02) \text {, beliefs about its harms } \\
(p=0.05) \text { and quitting commitment ( } p=0.01 \text { ) scores were } \\
\text { found to be higher for the experimental group than the } \\
\text { control group. }\end{array}$ \\
\hline $\begin{array}{l}\text { Pollak et al. } \\
\text { (2013) }\end{array}$ & $\begin{array}{l}\text { Support message } \\
\text { (group I)= } 15 \text { Support } \\
\text { Text message+ } \\
\text { gradually smoking } \\
\text { cessation text } \\
\text { messages (group } \\
\text { II) }=16\end{array}$ & $\begin{array}{l}5 \text { messages were sent daily for } 5 \text { weeks to the group } \\
\text { I to choose a date to quit smoking within } 2-3 \text { weeks. } \\
\text { Warning messages were sent to the group II for } 5 \\
\text { weeks to quit smoking completely at the end of the } \\
4^{\text {th }} \text { week. }\end{array}$ & 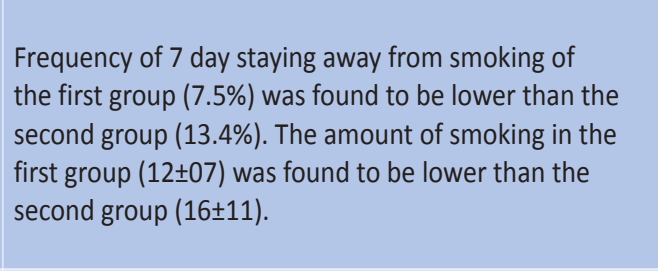 \\
\hline $\begin{array}{l}\text { Moniz et al. } \\
\text { (2013) }\end{array}$ & $\begin{array}{l}\text { General Care } \\
\text { Group }=100 \\
\text { General Care+text } \\
\text { message group }=104\end{array}$ & $\begin{array}{l}\text { General care group was received general health text } \\
\text { messages during pregnancy for } 12 \text { weeks, } \\
\text { General care+text message group was received text } \\
\text { messages about health+ influenza vaccine during } \\
\text { pregnancy for } 12 \text { weeks. }\end{array}$ & $\begin{array}{l}\text { At the end of the study, no difference was found } \\
\text { between the influenza vaccination rate of the general } \\
\text { care group (31\%) and the influenza vaccination rate } \\
(33 \%) \text { of the general care+ influenza vaccine group } \\
(p>0.05) \text {. }\end{array}$ \\
\hline $\begin{array}{l}\text { Stockwell et } \\
\text { al. (2014) }\end{array}$ & $\begin{array}{l}\text { Experimental } \\
\text { Group }=576 \\
\text { Control group }=577\end{array}$ & $\begin{array}{l}\text { Test group was received } 5 \text { text messages containing } \\
\text { information about influenza vaccine and } 2 \text { reminder } \\
\text { messages for } 5 \text { weeks, } \\
\text { Control group was received } 2 \text { reminder messages. }\end{array}$ & $\begin{array}{l}\text { At the end of the study, the vaccination rate of the } \\
\text { experimental group ( } 61.9 \% \text { ) was found to be higher than } \\
\text { the control group ( } 49 \%) \text {. }\end{array}$ \\
\hline $\begin{array}{l}\text { Jordan et al. } \\
\text { (2015) }\end{array}$ & $\begin{array}{l}\text { Text message group } \\
=3021 \\
\text { Education group } \\
=3820\end{array}$ & $\begin{array}{l}\text { Encouraging and reminder messages were sent to the } \\
\text { one group, specific health education messages were } \\
\text { sent to the other group. }\end{array}$ & $\begin{array}{l}\text { It was found that the reminder messages increased the } \\
\text { vaccination probability in mothers at the end of the year } \\
\text { and pregnant women thinking to have vaccine. Health } \\
\text { education not effective plan to have vaccine. }\end{array}$ \\
\hline $\begin{array}{l}\text { Cheng et al. } \\
\text { (2008) }\end{array}$ & $\begin{array}{l}\text { Text messages grup } \\
=1360 \\
\text { Control } \\
\text { Group }=1422\end{array}$ & $\begin{array}{l}\text { Screening test results were sent to the group } \\
\text { receiving text messages before the appointment, } \\
\text { Test results were given to the group not receiving } \\
\text { text messages during the appointment. Their anxiety } \\
\text { status were evaluated before and } 3 \text { days after the } \\
\text { appointment. }\end{array}$ & $\begin{array}{l}\text { Anxiety level of text messages group was found to be } \\
\text { lower before the appointment }(33.8 \pm 7.9) \text { than those } \\
(39.1 \pm 10.1) \text { who did not }(p=0.02) \text {. }\end{array}$ \\
\hline $\begin{array}{l}\text { Evans et al. } \\
\text { (2012) }\end{array}$ & $\begin{array}{l}\text { Intervention group= } \\
48 \\
\text { Control group }=38\end{array}$ & $\begin{array}{l}\text { Text messages about healthy lifestyle behaviors were } \\
\text { sent to the intervention group during the pregnancy. } \\
\text { Any application was not performed on control group. } \\
\text { Pregnant women were evaluated again 2-3 months } \\
\text { after the intervention. }\end{array}$ & $\begin{array}{l}\text { The statement "I am ready to be a mother" for the } \\
\text { pregnant women receiving Text } 4 \text { baby sms contents } \\
\text { increased compared to the beginning and follow-up } \\
(p=0.04) \text {. A positive development was determined in } \\
\text { their attitudes towards alcohol consumption }(p=0.02) \text {. } \\
\text { No change occurred in the control group }(p>0.05) \text {. }\end{array}$ \\
\hline $\begin{array}{l}\text { Evans et al. } \\
\text { (2014) }\end{array}$ & $\begin{array}{l}\text { Intervention group } \\
=229 \\
\text { Control group }=230\end{array}$ & $\begin{array}{l}\text { text message about healthy lifestyle behaviors during } \\
\text { the pregnancy were weekly sent to intervention } \\
\text { group for } 4 \text { weeks according to their gestational week, } \\
\text { No application was applied to the control group. }\end{array}$ & $\begin{array}{l}\text { Beliefs of the pregnant women receiving vitamin intake } \\
\text { during pregnancy increased (OR } 1.91,95 \% p=0.02) \text {. } \\
\text { Additionally, their beliefs towards the importance } \\
\text { of prenatal care }(p=0.04 \text { ) and the harms of alcohol } \\
\text { consumption ( } p=0.05) \text { were found to increase. }\end{array}$ \\
\hline $\begin{array}{l}\text { Evans et al. } \\
\text { (2015) }\end{array}$ & $\begin{array}{l}\text { Intervention group= } \\
230 \\
\text { Control } \\
\text { group }=220\end{array}$ & $\begin{array}{l}\text { Women in the intervention group were followed up } \\
3 \text { times (after } 4 \text { weeks, in } 28^{\text {th }} \text { week and right after } \\
\text { the birth) and they received weekly } 3 \text { text messages } \\
\text { according to their gestational weeks. } \\
\text { No intervention was applied to the control group. }\end{array}$ & $\begin{array}{l}\text { At the end of the study, text messages were found to } \\
\text { affect postpartum alcohol consumption of women in the } \\
\text { intervention group }(p=0.04) \text {. }\end{array}$ \\
\hline $\begin{array}{l}\text { Lau et al. } \\
\text { (2014) }\end{array}$ & $\begin{array}{l}\text { Intervention group } \\
=102 \\
\text { Control } \\
\text { group }=104\end{array}$ & $\begin{array}{l}\text { Starting to send 3-4 messages in a week to the } \\
\text { women in the intervention group about increasing } \\
\text { their health knowledge in pregnancy. No intervention } \\
\text { was applied to the control group. }\end{array}$ & $\begin{array}{l}\text { No significant difference was found between the } \\
\text { pregnancy health knowledge scores of intervention and } \\
\text { control groups }(p>0.05) \text {. }\end{array}$ \\
\hline $\begin{array}{l}\text { Lund (2014) } \\
\text { et al. }\end{array}$ & $\begin{array}{l}\text { Intervention group = } \\
1311 \\
\text { Control } \\
\text { group }=1239\end{array}$ & $\begin{array}{l}\text { Weekly text messages about the subjects like the } \\
\text { changes in the pregnancy in the intervention group. } \\
\text { No intervention was applied to the control group. }\end{array}$ & $\begin{array}{l}\text { Mortality rate of the intervention group ( } 19 \% \text { ) was } \\
\text { lower than the control group ( } 36 \% \text { ) at the end of } \\
\text { the study. In addition, the intervention was found to } \\
\text { be associated with a significant reduction in perinatal } \\
\text { mortality rate (OR0.50, Cl:0.27-0.93, confidence interval } \\
\text { of 95). }\end{array}$ \\
\hline
\end{tabular}




\begin{tabular}{|c|c|c|c|}
\hline $\begin{array}{l}\text { Soltani } \\
\text { (2015) et al. }\end{array}$ & $\begin{array}{l}\text { Intervention group } \\
=14 \\
\text { Control } \\
\text { group }=15\end{array}$ & $\begin{array}{l}\text { Daily messages encouraging healthy diet and } \\
\text { physical activities were sent to the women from the } \\
\text { intervention group. No intervention was applied to } \\
\text { the control group. }\end{array}$ & $\begin{array}{l}\text { Mean weight gain of women in the intervention group } \\
\text { during the pregnancy }(6.65 \mathrm{~kg}) \text { was found to be lower } \\
\text { than the control group }(9.74 \mathrm{~kg}) \text {. }\end{array}$ \\
\hline $\begin{array}{l}\text { Odeny (2014) } \\
\text { et al. }\end{array}$ & $\begin{array}{l}\text { Intervention group } \\
=195 \\
\text { Control } \\
\text { group }=193\end{array}$ & $\begin{array}{l}8 \text { text messages during the pregnancy period and } 8 \\
\text { text messages during the postpartum period were } \\
\text { sent to the women in the intervention group. } \\
\text { No intervention was applied to the control group. }\end{array}$ & $\begin{array}{l}\text { As a result of the study, } 19.6 \% \text { of women in the } \\
\text { intervention group and } 11.8 \% \text { of women in the control } \\
\text { group applied to clinic during the postpartum period. }\end{array}$ \\
\hline $\begin{array}{l}\text { Van Ryswyk } \\
\text { et al. (2015) }\end{array}$ & $\begin{array}{l}\text { Intervention group } \\
=140 \\
\text { Control } \\
\text { group }=136\end{array}$ & $\begin{array}{l}\text { Messages were sent to women in the intervention } \\
\text { group for reminding to have OGTT test in postpartum } \\
6^{\text {th }} \text { week and } 3^{\text {rd }} \text { and } 6^{\text {th }} \text { months; reminder message } \\
\text { was sent to women in control group in postpartum } \\
6^{\text {th }} \text { month. }\end{array}$ & $\begin{array}{l}\text { OGTT participation of the intervention group ( } 77.6 \%) \\
\text { were found not to increase in postpartum } 6^{\text {th }} \text { month } \\
\text { compared to the control group }(76.8 \%) \text { at the end of the } \\
\text { study. }\end{array}$ \\
\hline $\begin{array}{l}\text { Perez Ferre } \\
\text { (2010) et al. }\end{array}$ & $\begin{array}{l}\text { Intervention group } \\
=48 \\
\text { Control group }=49\end{array}$ & $\begin{array}{l}\text { Glucometers and mobile phones were given to the } \\
\text { women in the intervention group } \\
\text { No intervention was applied to the control group }\end{array}$ & $\begin{array}{l}\text { At the end of the study, clinical visit of the experimental } \\
\text { group reduced at the rate of } 2 \% \text {. While the average } \\
\text { clinic visit number was } 4.25 \text { in the experimental group, it } \\
\text { was } 9.11 \text { in the control group. }\end{array}$ \\
\hline
\end{tabular}

\subsection{Effect on Reducing Anxiety}

Pregnancy is one of the most important periods in a woman's life; not only in physical directions, but also in a number of social and psychological changes. Table 1 shows studies on the effect of text messages on reducing anxiety. Study subjects included come clinic for prenatal screen test. Result of one studies was determined text messages not effective for reducing anxiety (23).

\subsection{Effect on The Text4 Baby Program}

Result of studies text 4 baby program increased pregnant women state ready to be a mother, developed negative attitudes towards alcohol consumption (24). Also text4 baby program increased pregnant women beliefs about taking vitamin during pregnancy, the importance of prenatal care, and the harms of alcohol consumption increased $(24,25)$ (Table 1$)$.

\subsection{Effect on Text Messages Antenatal Health Knowledge and Awareness}

Adequate antenatal care is important to both the health of a pregnant woman and her unborn baby. Result of this study text messagges found to be not effective for antenatal health knowlwedge and awaraness $(26,27)$ (Table 1).

\subsection{Effect on Text Messages Reducing Obesity}

Mother obesity and excessive gestational weight gain (GWG) negatively affect pregnancy and delivery outcomes. Result of this study text messagges found to be effective for weight gain during pregnancy (28) (Table 1).

\subsection{Effect on Text Messages Having HIV Test}

Mobile health (mHealth) interventions have been shown to improve adherence to HIV test among adults and improve health service usage (29). The result of this rewiev text messagges found to be increased having HIV test pregnant woman (30) (Table 1).

\subsection{Effect on Text Messages Diabetes Management}

Gestational diabetes mellitus is defined as new onset or recognition of glucose intolerance in pregnancy (31). The result of this rewiev text messagges found to reduced clinical visits diabetic pregnant woman (32) (Table 1).

\section{DISCUSSION}

Our results suggest that text messages interventions that appear to have positive effects on pregnant women's health. For example that text messages were found to have positive effects on on smoking cessation and reduction of pregnant women (33-35).

It was found that only sending short text messages to pregnant women was not effective in influenza vaccination (17), but in addition to short messages, the use of reminder messages was found to be effective $(21,36)$.

Result of this rewiev text4 baby program increased pregnant women's motherhood readiness, negative attitudes against alcohol usage, beliefs about vitamin intake during pregnancy $(23,24)$.

Result of this rewiev found that text messages are effective in antenatal health knowledge and awareness, increasing nutrition knowledge and creating behavioral changes in the fight against obesity among the individuals $(27,28,37,38)$.

Text messages are suitable and useful in the self-management of diabetes (39). One of studies on the use of text message in diabetes management in pregnancy, reminder messages for Oral Glicoz Tolarence Test (OGTT) were determined not to be effective in pregnant women, but decreased the clinic visit rates (40). 
Our results show that some of the positive effects of text message interventions on pregnant women's health, however text message not effective for reducing anxiety. Although there is suggestive evidence of benefit in pregnant health, more research is needed to identify the other areas effect on pregnant health.

The limitation of our review is that we excluded all studies that did not report RCT results, another limitation of the review process may lead to a restriction (English).

\section{CONCLUSION}

Our review including the 15 studies results of RCTs of interventions that text messages interventions for pregnant women. This systematic review suggests use of text message is more practical and cost-effective method for promoting the health of pregnant women and they had a positive effect on health practices of pregnant women.

Conflicts of Interest: Authors declare that there is no conflict of interest.

Financial Disclosure: Financial support has not been taken.

\section{REFERENCES}

[1] Cole Lewis H, Kershaw T. Text messaging as a tool for behavior change in disease prevention and management. Epidemiol Rev 2010; 32(1):56-69.

[2] Abroms LC, Ahuja M, Kodl Y, Thaweethai L, Sims J, Winickoff JP, Windsor RA. Text2Quit: results from a pilot test of a personalized, interactive mobile health smoking cessation program. J Health Commun 2012; 17(1):44-53.

[3] World Health Organization. mHealth: New horizons for health through mobile technologies: Second global survey on eHealth. Global observatory for e health series. Switzerland: WHO Press 2011; 5-7.

[4] Yoon KH, Kim HS. A short message service by cellular phone in type 2 diabetic patients for 12 months. Diabetes Res Clin Pract 2008; 79(2):256-61.

[5] Kevin Patrick, Fred Raab, Marc Adams, Lindsay Dillon, Marion Zabinski, Cheryl Rock, William Griswold, Gregory Norman. Works citing a text message-based intervention for weight loss: randomized controlled trial. J Med Internet Res 2009; 11: e1.

[6] Riley WT, Rivera DE, Atienza AA, Nilsen W, Allison SM, Mermelstein R. Health behavior models in the age of mobile interventions: are our theories up to the task? Transl Behav Med 2011;1(1):53-71.

[7] Lunny C, Taylor D, Memetovic J, Warje O, Lester R, Wong T. Short message service (SMS) interventions for the prevention and treatment of sexually transmitted infections: a systematic review protocol. Syst Rev 2014; 3(7):1-8.

[8] Tirado M. Role of mobile health in the care of culturally and linguistically diverse US populations. Perspective Health Inf Manag 2011; 1(8):1e.

[9] Holtz B, Lauckner C. Diabetes management via mobile phones: a systematic review. Telemed J E Health 2012; 18(3):175-84.
[10] Lim EJ, Haar J, Morgan J. Can text messaging results reduce time to treatment of Chlamydia trachomatis? Sex Transm Infect 2008; 84(7): 563-64.

[11] Parker RM, Dmitrieva E, Frolov S, Gazmararia JA. Text4baby in the United States and Russia: An opportunity for understanding how mHealth affects maternal and child health. J Health Commun 2012; 17(1):30-36.

[12] Evans WD, Wallace JL, Snider J. Pilot evaluation of the text4baby mobile health program. BMC Public Health 2012; 12: 1031.

[13] Qiang CZ, Yamamichi M, Hausman V, Miller R, Altman D. Mobile applications for the health sector. World Bank Rep. Washington DC, 2012.

[14] Systematic Reviews. CRD's guidance for undertaking reviews in health care. Centre for Reviews and Dissemination, University of York 2009.

[15] Karacam Z. Systematic review methodology: A guide for preparation of systematic review. Dokuz Eylul University School of Nursing Electronic Journal 2013; 6(1): 26-33.

[16] Moher D, Liberati A, Tetzlaff J, Altman DG. The PRISMA group. Preferred reporting items for systematic reviews and metaanalyses: The PRISMA statement. Int J Surg 2010; 151(4):26469.

[17] Higgins JPT, Altman DG, Gotzsche PC, Jüni P, Moher D, Oxman $A D$ et al. Cochrane statistical methods group. The Cochrane Collaboration's tool for assessing risk of bias in randomized trials. BMJ 2011; 18(343):1-9.

[18] Pollak KI, Lyna P, Bilheimer A, Farrell D, Gao X, Swamy GK. A pilot study testing sms text delivered scheduled gradual reduction to pregnant smokers. Nicotine Tob Res 2013; 15(10): 1773-76.

[19] Naughton F, Prevost AT, Gilbert H, Sutton S. Randomized controlled trial evaluation of a tailored leaflet and SMS text message self-help intervention for pregnant smokers (MiQuit). Nicotine Tob Res 2012; 14(5): 569-77.

[20] Fiore AE, Uyeki TM, Broder K, Finelli L, Euler GL, Singleton JA, Iskander JK, Wortley PM, Shay DK, Bresee JS, Cox NJ; Centers for Disease Control and Prevention (CDC). Prevention and control of influenza with vaccines: recommendations of the Advisory Committee on Immunization Practices (ACIP), 2010. MMWR Recomm Rep. 2010;59(RR-8):1-62.

[21] Moniz MH, Hasley S, Meyn LA, Beigi RH. Improving influenza vaccination rates in pregnancy through text messaging: a randomized controlled trial. Obstet Gyneloc 2013; 121(4): 734-40.

[22] Jordan ET, Bushar J, Kendrick J, Johnson P, Wang J. Encouraging influenza vaccination among text4baby pregnant women and mothers. Am J Prev Med 2015; 49(4):563-72.

[23] Cheng PJ, Wu TL, Shaw SW, Chueh HY, Lin CT, Hsu JJ, Hsieh $\mathrm{TT}$, Soong YK. Anxiety levels in women undergoing prenatal maternal serum screening for Down syndrome: The effect of a fast reporting system by mobile phone short-message service. Prenat Diagn 2008; 28(5):417 - 21.

[24] Evans WD, Wallace Bihm J, Szekely D, Nielsen P, Murray E, Abroms L, Snider J. Initial outcomes from a 4-week follow-up study of the text4baby program in the military women's population: randomized controlled trial. J Med Internet Res 2014; 16(5): e131.

[25] Evans W, Nielsen PE, Szekely DR, Bihm JW, Murray EA, Snider J, Abroms LC.Dose-response effects of the text4baby mobile 
health program: randomized controlled trial. JMIR Mhealth Uhealth 2015; 3(1):1-13.

[26] Lau YK, Cassidy T, Hacking D, Brittain K, Haricharan HJ, Heap $M$. Antenatal health promotion via short message service at a midwife obstetrics unit in South Africa: A mixed methods study. BMC Pregnancy Childbirth 2014; 14(284): 1-8.

[27] Lund S, Rasch V, Hemed M, Boas IM, Said A, Said K, Makundu $\mathrm{MH}$, Nielsen BB. Mobile phone intervention reduces perinatal mortality in Zanzibar: Secondary outcomes of a cluster randomized controlled trial. JMIR Mhealth Uhealth 2014; 26(1): e15.

[28] Soltani H, Duxbury AMS, Arden MA, Dearden A, Furness PJ, Garland C. Maternal obesity management using mobile technology: A feasibility study to evaluate a text messaging based complex intervention during pregnancy. J Obes 2015; 2015:1-10.

[29] Pop-Eleches C, Thirumurthy H, Habyarimana JP, Zivin JG, Goldstein, MP, Walgue D. Mobile phone technologies improve adherence to antiretroviral treatment in a resourcelimited setting: a randomized controlled trial of text message reminders. AIDS 2011; 25(6):825-34.

[30] Odeny TA, Bukusi EA, Cohen CR, Yuhas K, Camlin CS, McClelland RS. Texting improves testing: a randomized trial of two-way SMS to increase postpartum prevention of mother-to-child transmission retention and infant HIV testing. AIDS 2014; 28(15): 2307-12.

[31] Mackillop L, Loerup L, Bartlett K, Farmer A, Gibson OJ, Hirst $J E$. Development of a real-time smartphone solution for the management of women with or at high risk of gestational diabetes. J Diabetes Sci Technol 2014; 8(6):1105-14.

[32] Perez Ferre, N, Galindo M, Fernandez M.D, Velasco V, Runkle, I, Cruz MJ. The outcomes of gestational diabetes mellitus after a telecare approach are not inferior to traditional outpatient clinic visits. Int J Endocrinol 2010; 2010: 1-6.
[33] Dodd JM, Grivell RM, Crowther C, Robinson JS. Antenatal interventions for overweight or obese pregnant women: a systematic review of randomized trials. BJOG 2010; 117(11):1316-26.

[34] Ybarra ML, Holtrop JS, Bağci Bosi AT, Bilir N, Korchmaros JD, Salih Emri AK. Feasibility and acceptability of a text messagingbased smoking cessation program in Ankara, Turkey. J Health Commun 2013; 18(8):960-73.

[35] Keoleian V, Polcin D, Galloway GP. Text messaging for addiction: A review. J Psychoactive Drugs 2015; 47(2):158-76.

[36] Stockwell MS, Westhoff C, Kharbanda EO, Vargas CY, Camargo $S$, Vawdrey DK, Castaño PM. Influenza vaccine text message reminders for urban, low-income pregnant women: A randomized controlled trial. Am J Public Health 2014; 104(1):712.

[37] Price S, Ferisin S, Sharifi M, Steinberg D, Bennett G, Wolin KY, Horan C, Koziol R, Marshall R, Taveras EM. Development and Implementation of an interactive text messaging campaign to support behavior change in a childhood obesity randomized controlled trial. J Health Commun 2015; 20(7):843-50.

[38] Brown ON, O'Connor LE, Savaiano D. Mobile myplate: A pilot study using text messaging to provide nutrition education and promote better dietary choices in college students. J Am Coll Health 2014; 62(5): 320-27.

[39] Dobson R, Whittaker R, Jiang $Y$, Shepherd M, Maddison R, Carter K, Cutfield R, McNamara C, Khanolkar M, Murphy R. Text message-based diabetes self-management support (SMS4BG): study protocol for a randomized controlled trial. Trials 2016; 2(17):1-10.

[40] Van Ryswyk EM, Middleton PF, Hague WM, Crowther CA. Postpartum SMS reminders to women who have experienced gestational diabetes to test for Type 2 diabetes: The DIAMIND randomized trial. Diabet Med 2015; 32(10):1368-76. 